\title{
The pragmatic approach of Indian railways in outlasting the sustainable development
}

\author{
Shahid Ali 1,", Aijaz Ahmad Mir ${ }^{2}$ \\ Research Scholar, Dept. of Management Studies, Islamic University of Science and Technology, Awantipora, Jammu \&Kashmir \\ *Corresponding Author: \\ Email: dihah7692@yahoo.com
}

\begin{abstract}
The effervescent growth of the services rendered by Indian railways in satisfying the passenger needs in the current scope of the business development leads its coverage over the macro segments of social, economic and environmental development. Even after the necessary efforts and literature analysis by the various researchers, the scope of contributions by the Indian Railways towards Sustainable Development remains a less discussed. The present paper focuses on the pivotal role of Indian railways Services in the Sustainable Development by contributing towards social, economic and environmental aspects of the society. The paper also highlights the key factors that need immediate attention by the concerned authorities under the respective segments in order to provide a proper platform for the Sustainable Development.
\end{abstract}

Keywords: Services, Sustainable Development and Indian Railways.

\section{Introduction}

A Service is an act of performance that one party can offer to another that is essentially intangible and does not result in the ownership of anything. Its production may or may not be tied to a physical product. ${ }^{1}$

In the modern era, service sector contributes a huge share in the Indian economy and it is the lifeline for the socio economic growth of a country. One of the reasons behind the growth of the service sector is due to the increase in demand for immediate quality passenger services offered by railways. The service sector in India includes various sectors like transportation, communication, banking, health, etc. Transportation through rails called Rail Transport play a vital role in the development of a country. Railway mean a track made of steel rails along which trains run; a network of tracks with the trains, organization, and personnel required for its working. Railways help to unite the people who inhabit in different regions of the country. It further connects Centre's of commerce and industry, pilgrim Centre's, historical sites and important tourist Centre's. It provides employment to millions of people.

Indian Railways (IR) is an Indian state-owned enterprise, owned and operated by the Government of India through the Ministry of Railways. It is one of the world's largest railway networks comprising 1, $15,000 \mathrm{~km}$ of track over a route of $67,312 \mathrm{~km}$ and 7,112 stations. As for rolling stock, IR holds over 2, 45,267 Freight Wagons, 66,392 Passenger Coaches and 10, 499 Locomotives (43 steam, 5,633 diesel and 4,823 electric locomotives). ${ }^{2}$ Indian Railways provide the services relating to passenger services, freight services, parcel services, catering services, tourism services, parking lot operations and other related services.

World Commission on Environment and Development $1987^{3}$ states Sustainable Development as
"Development that meets the needs of the present without compromising the ability of future generations to meet their own needs" or it can be defined as an economic and social development that meets the needs of present generation without endangering the possibilities of future generations to do so i.e. development has to happen within the environmental limits of earth. Sustainable Development is based on three pillars namely social, environmental and economic where the social and economic progress are all attainable within the limits of our earth's natural resources i.e., environmental. Sustainability aims to optimize the relation between social, economy and environment.

Three Pillar Basic Model: This is one of the most well-known models created using the three dimensions -Economy, Environment and Society. The diagram shows three interlocking circles with the triangle of environmental (conservation), economic (growth), and social (equity) dimensions. ${ }^{4}$

\section{Dimension of Sustainability}

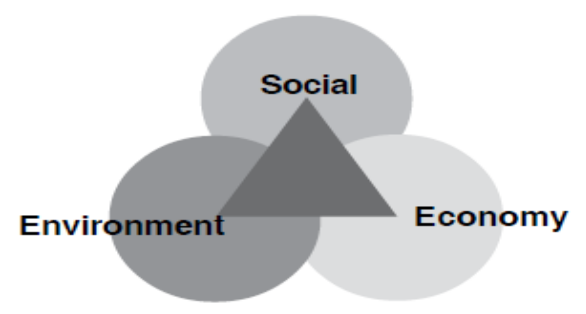

Fig.1: A sketch from Aparna Susarla and Keren Nazareth (2007), Sustainable Development: An Introduction) 


\section{Objectives of the Study}

1. To study the conceptual view of role of railways in sustainable development.

2. To study the Indian Railways services contribution towards economic, social and environment development.

\section{Role of Railways in Sustainable Development}

Pogutz et al. ${ }^{5}$ states eco-efficiency as a concept has very close connection to the ideas of Sustainable Development.

One of the approaches to eco-efficient services is offered by use-oriented services, which provide value for the customer by allowing access to the product and to the function it provides. The customer only pays for the access and the use. That means the railway services are use-oriented services. ${ }^{6}$

Eco-efficiency focuses on economic and ecological efficiency and does not take into account social sustainability, even though ecological, economic and social sustainability are strongly intertwined. ${ }^{7-10}$ Thus eco-efficiency is not sufficient for sustainable development. That means all the three ecological, economic and social sustainability are necessary for the Sustainable Development.

Rail transportation has a number of favourable characteristics as compared to road transportation. It is six times more energy-efficient than road and four times more economical. The social costs in terms of environment damage or degradation are significantly lower in rail. Rail construction costs are approximately six times lower than road for comparable levels of traffic. It is the only major transport mode capable of using any form of primary energy. ${ }^{11}$

The ten principles that are fundamental to the role rail can play in a sustainable transport system and fundamental to the sustainability of rail itself. These principles are: Customer driven, Putting rail in reach of people, Providing an end to end journey, Being an employer of choice, Reducing our environmental impact, Carbon smart, Energy wise, Supporting the economy, Optimising the railway, Being transparent. ${ }^{12}$ This reveals the III coverage and scope of development of all the three basic pillars namely ecological, economic and social aspects can be attained through the railway services.

\section{Indian Railways Services Contribution towards} Economic Development

The Indian Railways has served to integrate the fragmented markets and helped to unite the people from different regions of the country. It promotes industrial development by connecting industrial production centres with sources of raw materials and with markets. Further Indian
Railways connects centres of commerce and industry, pilgrim centres, historical sites and important tourist centres. It links places, enabling large-scale, rapid and low-cost movement of people across the country. It provides rapid, reliable and cost-effective bulk transportation. Railway services being fast and safe, enables the traders to reduce their stock holdings. It provides employment to the millions of people of the country. Indian Railways provide the services relating to passenger services, freight services, parcel services, catering services, tourism services, parking lot operations and other related services.

India ranks $11^{\text {th }}$ in the service sector of the world GDP and $10^{\text {th }}$ in the overall GDP. Service sector in India has a Compound Annual Growth Rate (CAGR) of $8.7 \%$ (second to the China, $10.7 \%$ ) from 2001-13. In 2013, India's share of service sector is $57 \%$ in GDP. The Indian Railways contributes to India's economic development, accounting for about $0.9 \%$ of GDP and the backbone of passenger and freight needs of the core sector ${ }^{13}$. Also, the share of the transport service sector is $6.7 \%$ in the overall GDP. In last 64 years, Route kilometres have grown by $23 \%$, freight carried by $1344 \%$ and passenger kilometres by $1642 \% .{ }^{14}$ This depicts the growth of passenger and freight services and its huge contribution to the economic development.

Parcel services (non-core business of Indian Railways) have a potentially huge market in India. In 2013-14, Indian Railways earned Rs. 1827.60 crore with variation over last year about $11.7 \%$ increase. The services sector is not only the dominant sector in India's GDP, but has also attracted significant foreign investment flows. Government of India in August, 2014 has permitted Foreign Direct Investment in construction, maintenance and operation of the identified areas in Indian Railways. Freight and passenger traffic carried by the Indian Railways has recorded an impressive growth ever since Independence. This depicts the role of Indian Railways in contributing to the sustainability of economy.

\section{Indian Railways Services Contribution towards Social and Environment Development}

Energy sustainability, Safety and Social initiatives are among the eleven major thrust areas of Action Plan (2015-19), Railway Budget 201516. During the year 2013-14, 69.13 lakh saplings were planted on railway land. Indian Railways envisages sourcing of at least $10 \%$ of energy used from renewable sources such as solar power and wind power. Development of composite sleepers made of a polymer matrix, typically polyethylene (HDPE), with reinforcing fibres is being done as an alternative to wooden sleepers. Use of Common 
Rail Direct Injection (CRDI) as fuel injection system leads to reduction in fuel consumption, reduction of emissions to very low levels and reduction of engine combustion generated noise. Indian Railways plays a vital role in sustaining traffic volume in an environment of moderate growth ${ }^{15}$. This depicts the role of Indian Railways in contributing to the sustainability of environment.

Indian Railways Price distortions keep the low fare for passenger's leads to a hike in freight tariffs. ${ }^{16}$ Indian Railways are providing certain goods and passenger services at below the cost of operation. The losses accruing from such operations, which are justified for meeting wider socio-economic objectives, are termed as 'Social Service Obligation'. The losses are Rs. 2, 48,863 (in millions) (excluding staff welfare and law \& order costs). Railways also bear social service obligation of around Rs.25,000cr every year by carrying passenger services below cost. This depicts the role of Indian Railways in contributing to the sustainability of social services.

IV. Research Methodology

Research Design: On the basis of purpose of study, the research paper applies qualitative and quantitative aspects based on secondary data analysis.

On the basis of time dimension, it is a Crosssectional study as it was carried out once and represents a snapshot of one point in time.

Area of Research: The service sector in India includes various sectors like transportation, communication, banking, health, etc. This paper focus on the Indian Railway services that falls under the transport service sector.

Sources of Data and Analysis: Secondary data is used to create a theoretical background of the Study and to analyze the data in context of services in Indian Railways through previously available information in the form of Articles, Journals, Editorials, Research Papers and Books.

\section{Findings, Suggestions and Conclusion}

1. The findings indicate a strong relation between the services and the three basic pillars namely ecological, economic and social aspects that can be attained through the railway services. In railways, economical sustainability as such is not sufficient, the other two namely social and environmental sustainability need to be considered for overall sustainable development.

2. The three thrusts namely Energy sustainability, Safety and Social initiatives which are among the eleven major thrust areas of Action Plan (2015-19) must be implemented in order to attain the overall sustainability of environment and social aspect.
3. Parcel services (non-core business of Indian Railways) need to be strengthened.

4. Indian Railways must maintain the Social Service Obligation in order to sustain the social aspect of sustainable development.

5. Efforts should be made to generate confidence among the investors for participation of private sector in creation of Rail infrastructure.

6. Indian Railways must meet the demands of its customers, both freight and passenger. Regarding the passenger services, quality delivery through various services need urgent attention.

7. Creation of capacity, eliminating capacity bottlenecks, modernization of network, improvement in asset utilization, efficiency of operations, optimal employment of its resources and productivity. This will ensure that rail travel is an experience beyond other modes of travel.

8. WCED 1987 states Sustainable Development as "Development that meets the needs of the present without compromising the ability of future generations to meet their own needs". Also, Eco-efficiency services focuses on ecology and economic sustainability and does not take into account social sustainability. That means all the three ecological, economic and social sustainability are necessary for the Sustainable Development regarding the services. India ranks 11 th in the service sector of the world GDP with a CAGR of $8.7 \%$. Indian Railways services are of utmost importance to attain the overall sustainable development and are envisioned to greatly contribute in terms of social, environmental and economic aspects. Indian Railways as a core fragment of service sector in India is playing a robust role in the economic development of India. Growth in services like freight services, passenger services, and parcel services at par contribute to the sustainable development. Thrust areas of Action Plan (2015-19) like Energy sustainability, Safety and Social initiatives are key areas for maintaining a sustainability of Indian railway services.

\section{References}

1. Kotler P. Marketing management: analysis, planning, implementation, and control. 1990.

2. Indianrailways.gov.in. Indian Railways Official Website. 2015 [cited 2017 Oct 24] Available from:

http://indianrailways.gov.in/railwayboard/uploads/directo rate/stat_econ/IRSP_2013-

14/pdf/Statistical_Summary/Summary\%20Sheet_Eng.pdf

3. Brundtland GH. Report of the World Commission on environment and development:" our common future." United Nations; 1987. 
4. Susarla A. and Nazareth K. Sustainable Development: An Introduction. 1st ed. Gujarat, India: Centre for Environment Education; 2007.

5. Pogutz S, Micale V, Winn M. Corporate environmental sustainability beyond organizational boundaries: Market growth, ecosystems complexity and supply chain structure as co-determinants of environmental impact. Journal of Environmental Sustainability. 2011;1(1):39-60.

6. Stoughton M, Frantz C, Votta TJ and Krop R. Green Servicing for a More Sustainable US Economy: Key concepts, tools and analyses to inform policy engagement. Washington D.C.: US Environmental Protection Agency (USEPA), Office of Resource Conservation and Recovery;2009.

7. Welford R. Models of Sustainable Development for Business. In Richard Welford (ed.): Hijacking Environmentalism: Corporate Responses to Sustainable Development. London, UK;1997:179-210.

8. Hukkinen J. Eco-efficiency as abandonment of nature. Ecological Economics. 2001 Sep 30; 38(3):311-5.

9. Dyllick T, Hockerts K. Beyond the business case for corporate sustainability. Business strategy and the environment. 2002 Mar 1;11(2):130-41.

10. Ehrenfeld JR. Eco-efficiency: Philosophy, Theory, and Tools. Journal of Industrial Ecology. 2005;9(4):6-8.

11. Pib.nic.in. Press Information Bureau Official Website. 2015 [cited 2017 Oct 27] Available from: http://pib.nic.in/feature/fe0199/f1101991.html.

12. Rssb.co.uk. Rail Safety and Standards Board Official Website. 2011 [cited 2017 Dec 15] Available from: https://www.rssb.co.uk/Library/improving-industryperformance/2011-report-rail-industry-sustainabledevelopment-review.pdf.

13. Indianrailways.gov.in. Indian Railways Official Website. 2015 [cited 2018 Jan 02] Available from: http://www.indianrailways.gov.in/railwayboard/uploads/d irectorate/finance_budget/Budget_201516/English_Speech_Highlights_2015-16.pdf.

14. Prabhu SP. Indian Railways - Lifeline of the Nation (A White Paper). Volume 1. 2015 [cited 2017 Nov 02] Availablefromhttp://www.indianrailways.gov.in/railwayb oard/uploads/directorate/finance_budget/Budget_201516/White_Paper-_English.pdf.

15. Subramanian A. Economic Survey 2014-15. Volume 2. 2015 [cited 2017 Dec 25] India: GoI Department of Economic Affairs. Available from: http://indiabudget.nic.in/es2014-15/echapter-vol2.pdf.

16. Subramanian A. Economic Survey 2014-15. Volume 1. 2015 [cited 2017 Nov 22] India: GoI Department of Economic Affairs. Available from: http://indiabudget.nic.in/es2014-15/echapter-vol1.pdf. 